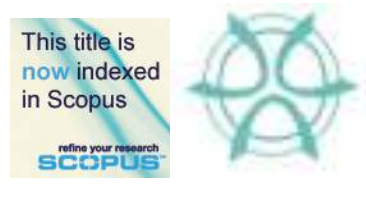

PLANNING MALAYSIA:

Journal of the Malaysian Institute of Planners

SPECIAL ISSUE IV (2016), Page 197 - 208

\title{
LIVEABILITY PLANNING FOR CITIES: WITHIN THE ISLAMIC FRAMEWORK OF MAQASID AL-SHARI'AH
}

\author{
Norimah Md Dali' ${ }^{1}$, Alias Abdullah² \& Azila Ahmad Sarkawi ${ }^{3}$ \\ 1,2,3 Kulliyyah of Architecture \& Environmental Design \\ INTERNATIONAL ISLAMIC UNIVERSITY MALAYSIA
}

\begin{abstract}
Liveability Planning is a new dimension of town planning practice. Town planning in Malaysia has been very physical and policy-biased. The soul component of liveability, quality of life and sustainability has been lacking. That is why environmental problems have now become the order of the day making urban living unhappy. Indeed liveability, quality of life and sustainability is one continuous process; a continuum. Conventional liveable indicators seem to concentrate more on economic and social wellbeing and lack religious elements. This gap is thought to be the missing link disabling human beings to live in harmony with nature. This research engages in the combined methodology which involves Focus Group Discussions, Interviews and Perception surveys in the formulation of the liveable city planning methodology based on Maqasid Al-Shari'ah (objectives of the Islamic Laws). Liveability planning practice that incorporate Maqasid into the conventional liveability indicators will render cities more liveable in the future.
\end{abstract}

Keyword: Liveability planning; Liveable indicators; Liveable city; Maqasid Al-Shari'ah.

\section{INTRODUCTION}

Critiques have it that the Malaysian town planning practice and the preparation of plans has been mundanely physical and policy-statements biased. This started since 1967 when the Town and Country Planning Act, Act 172 (Government of Malaysia 1976), was first enacted and adopted. Hence the National Physical Plan (National Physical Plan 2010), the Structure Plans, the Local Plans and the Special Area Plans when implemented were found full of loopholes and misinterpretations and in some cases blatantly maneuvered by developers for their maximization of profit pursuits. The brunt of this practice unfortunately has been backlashed by numerous environmental disasters and issues. Landslides, floods, air pollution, water woes, high mean temperatures and droughts have become rampant since the last two decades especially when urbanization and the economic development became the main agendas of the country.

Local governments on the other hand have been saddled with the task to create liveable cities, to offer quality of life and to fulfill sustainability objectives. Likewise, pressures of development in urban areas to cater for its inhabitant needs also form challenges especially to the town planners. Local Plans and Special Area Plans should therefore be cleverly customised for its residents' present as well as future needs. 
Norimah Md Dali, Alias Abdullah \& Azila Ahmad Sarkawi

Liveability Planning for Cities: Within the Islamic Framework of Maqasid Al-Shari'ah

Consciously or unconsciously Town planners aspire to create liveable cities. Liveable cities offer certain living standards and quality of life. This state of affairs when they have become the everyday norm of city living would of course be wished to be sustained and to be continuously enjoyed and be consistently improved. This is where Liveability Planning would take centre stage and play its role. Liveability and sustainability are two interrelated planning goals that have become the main agenda of sustainable development which had since been encompassed in the Brundtland Report (Burton 1987).

\section{Liveability Planning}

Liveability Planning is the result of the culmination of both the land use planning system which promotes the role of planning in creating liveable and sustainable cities and at the same time enhancing the wellbeing and quality of life of urban communities. As opposed to Physical Planning, elements of the People ware or Heart ware which is the core business of Maqasid Al-Shari'ah are to be integrated into the process of town planning and manifested into the lives of the peoples. Islamisation of town planning practice need to be inculcated towards ensuring liveability, quality of life, happiness and sustainability - all in one package. In fact it constitute as a continuum process. Indeed these are interrelated and influence each other towards quality living within the ambit of the environment, in this world and in the hereafter. Physical planning alone would not be able to deliver a complete urban living package and exude real happiness for the urban population. It has to be supported by the human factor itself; his purpose of life and his way of life as entrusted upon him by his creator. Maqasid al-Shari'ah or the objectives of Islamic Law has been provided by Allah as the 'manual' for man to lead his life on earth; in its destined manner.

Conventionally, Town Planning provides physical layouts for liveable neighbourhoods and provisions of high standards of urban services and social facilities that guarantee quality of life. It is then related directly to the quantity surveyors' Life Cycle Costing (LCC) that begins first by creating happiness which then attracts investors and subsequently promotes sustainable developments. It is able to create certain built environment, urbanscapes and city image. This is where the interconnectedness of town planning and architecture lie. However, present shortcomings of planning have arguably been too physical and too policy-biased which are not easily translated into quality, life cycle costing and happiness of peoples. Meanwhile, Maqasid Al-Shari'ah seems to standalone and have not been integrated with worldly concerns like town planning, quantity surveying and architecture in creating the built environment.

It is the contention of this study that Liveability planning could bridge this gap. Liveability aspects need to be interwoven with the other components of the built environment for the benefit of not only the "ummah" but for the universal human beings. This gap will have to be proven in this empirical research which involves case studies of two prominent towns of Malaysia i.e. Putrajaya and Shah Alam. Examinations on whether liveability planning has been consciously integrated with the Maqasid Al-Shari'ah and evaluation on whether the spiritual or religious wellbeing of the people have been emphasized or are lacking will be conducted.

The research will highlight the weaknesses occurring especially in the vagueness of current planning policies and plan statements, the meaning and the concept of liveability in the Maqasid Al-Shari'ah context with its three levels of importance to 
human lives i.e. Dharuriyyat(the essentials), Hajiyyat(the complementaries) and Tahsiniyyat(the desirables or the embellishments). Most importantly the surficial or minimal considerations of these values in the process of planning and its implementation will be highlighted. Thus, to overcome this shortcoming, liveability planning which integrate the conventional indicators and the Maqasid Al-Shari'ah indicators are strongly advocated.

\section{Maqasid Al-Shari'ah}

For the past two decades, liveable cities indicators have been dominated by Western methodologies of measurement. For comparison sake, this may be termed as the Conventional liveability Indicators or Indices as represented by the three renowned organizations i.e. Monocle, Mercer and EIU (STEEP 2013). Meanwhile numerous studies on Maqasid Al-Shari'ah too had been undertaken especially by Islamic Jurists and scholars since The Caliph Umar's reign until more recent debates by contemporary scholars like Auda (2008), Kamali and Kamali (2008) and Al and Chik (2011). These focus on benefits or objectives of Islamic Law that have to be abided by to take care of human intrinsic needs in life. However, upon examination of both disciplines; the conventional and the Maqasid Al-Shari'ah, it seems that they are not integrated to each other and had not been jointly highlighted to benefit human beings in a comprehensive manner.

This study therefore attempts to fill up this gap where the Islamic liveable cities indicators via Maqasid Al-Shari'ah, will be merged and incorporated into those conventional measurements to render the whole exercise more comprehensive, broad and dynamic for the ultimate benefits to all mankind. Together, the conventional methodology and the Maqasid Al-Shari'ah approach may effectively contribute to the possible solution of contemporary humanity problems. Contemporary Islamic scholars refer this form of civilizational renewal as Al-tajdid al-hadari or the agenda of civilizational renewal (Bakar 2015). Maqasid Al-Shari'ah comprises benefits, welfare and advantages behind the revelation of Islamic Laws for human beings and warding off evil, injury and loss. These are sometimes referred to as Masalih Al-'Ibad in Arabic. Maqasid Al-Shari'ah is concerned about the protection of life, faith, intellect; lineage and property for human beings. These are seen as absolute requirements for the survival and spiritual well-being of individuals and the public, without which it would lead to destruction, collapse, chaos and demise of the normal order of societies (Bakar 2015).

The Maqasid-cum-Masalih has been broken down into three levels of importance i.e. the Dharuriyyat, the Hajiyyat and the Tahsiniyyat. This theoretical framework of Maqasid Al-Shari'ah alias the "panca" (five) goals can be traced back to the administration of the second caliph, Umar bin al-Khattab (d. 644) and the Maliki School of Islamic jurisprudence, which emphasized public interest or Maslahah. In fact, the concept of Maqasid was first developed by the twelfth century theologian Abu Hamid alGhazali Abu Hamid al-Ghazali (d. 1111) who had pioneered the categorization of Maqasid Al-Shari'ah into the three descending categories of significance mentioned earlier.

Dharuriyyat (Essentials/ Necessities) are seen as absolute requirements for the survival and the spiritual well-being of individuals and communities. These objectives are musts and basic for the establishment of the general human welfare of this world and 
Norimah Md Dali, Alias Abdullah \& Azila Ahmad Sarkawi

Liveability Planning for Cities: Within the Islamic Framework of Maqasid Al-Shari'ah

the world hereafter. If they are ignored then the coherence and order cannot be established and chaos, disorder and loss will prevail.

Dharuriyyat relates to five things for human wellbeing and development (Kamali and Kamali 2008) as follows:

1) Protection of Faith/Belief (Din)

2) Protection of Life (Nafs)

3) Protection of Reason/Intellect ('Aql)

4) Protection of Posterity/Lineage (Nasl)

5) Protection of Property/Wealth. (Maal)

For example, in murder and burglary cases, the punishment is by Hudud laws, and for adultery cases, the punitive punishment is public throwing of stones till death. The severe punishment according to Shari'ah law must be executed in order to discipline mankind for long term benefits. Solah, zakah, fasting and hajj are compulsory for the maintenance of faith (din). Building mosque, Baitul Mal, clothing, housing, is meant to maintain life (Nafs). The safeguarding of 'Aql, Nasl and Maal are necessary to fulfill the objective of basic needs and essentials of a human life of the Dharuriyyat category.

The second category of benefits, the Hajiyyat or the complimentary benefits, seek to protect and promote the essential masalih on a secondary capacity. All such provisions of Shari'ah which aim at facilitating life and removing hardship are said to fulfill the Hajiyyat (requirements). Often those needs apply to individuals; for example during Ramadhan one may break fast when travelling or a Muslim lady may take off her hijab when being treated by a male doctor. Hence these waivers remove severity and hardship in cases where they do not pose threats to human survival (Sarkawi et al. 2008, Winkel 2011). Other examples of Hajiyyat include permission of hunting and use of halal goods for food, lodging, and conveyance, the permission for qirad (profit sharing through borrowing), musaqah (profit sharing) and bai salam (forward buying of a commodity which does not yet exist). Hajiyyat ruksah (concessions), such as the shortening of the Salah (prayer) during long distance travel and in battlefield, the forgoing of the fast by the sick, the traveller and masons or building workers are some more examples of Shari'ah provisions that aim at facilitating and removing hardships in life. Likewise in the criminal law, should there be doubts in reaching verdicts, penalties could be suspended. The general rule is that when there is a plurality of conflicting masalih and none appears to be clearly preferable, then the prevention of evil takes priority over the realisation of benefit. This is stressed by the Prophet's (Pbuh) hadith - "When I order you to do something, do it to the extent of your ability, but when I forbid you from something, then avoid it altogether".

The last category of benefits i.e. Desirables/Luxuries (Tahsiniyyat) involves good human being practices and mannerisms; for example a Muslim lady is to decorate or groom herself for the enjoyment of her husband, all Muslims should conduct table manners when eating and not to indulge in business involving "haram" products. Kamali and Kamali (2008) summarized this as seeking to attain refinement and perfection in customs and conduct of the people at all levels.

Shari'ah beautifies life and puts comforts into it. In fact, there are several provisions of the Shari'ah which are meant to ensure better utilization, beautification and simplification of the Dharuriyyat and the Hajiyyat in the form of the Tahsiniyyat. For 
example, permission to use beautiful, comfortable things; to eat delicious food, cleanliness of the body and attire for the purposes of 'ibadah, the use of perfume when attending Friday congregational prayer seek to attain refinement, comfort and perfection in the customs and conduct of people. The Shari'ah also encourages the giving of charity to those in need (sadaqah and waqaf) in the spirit of Tahsiniyyat.

\section{Liveable Cities}

The so-called World liveable cities indices by Monocles, EIU and Mercer even though covered a wide range of social, physical, economic, environmental and political aspects are not standardized (As illustrated by Table 1). Certain sectors take prominence than the other and within each sector various sub-components are examined and measured. Hence this resulted in different cities crowned as most liveable cities. Table 2 shows the 2014 top ten rankings of world liveable cities which obviously differ altogether but predominantly European-biased. Only Monocle recognized three Japanese cities as liveable though.

Table 1: Criteria used in the liveable cities index

\begin{tabular}{|c|c|c|c|}
\hline $\begin{array}{l}\text { World } \\
\text { Organization. }\end{array}$ & $\begin{array}{l}\text { EIU }^{1} \\
\text { (5 Categories ) }\end{array}$ & $\begin{array}{l}\text { MERCER }^{2} \\
\text { (10 categories })\end{array}$ & $\begin{array}{l}\text { MONOCLE } \\
\text { (12 categories ) }\end{array}$ \\
\hline \multirow[t]{5}{*}{ Criteria } & $\begin{array}{l}\text { 1) } 25 \% \text { Stability } \\
\text { Prevalence of crime, } \\
\text { threat of military } \\
\text { conflict, civil unrest \& } \\
\text { terrorism }\end{array}$ & $\begin{array}{l}\text { 1) Political \& Social } \\
\text { environment }\end{array}$ & $\begin{array}{l}\text { 1) Safety, Crime } \\
\text { 2) Tolerance }\end{array}$ \\
\hline & $\begin{array}{l}\text { 2) } 20 \% \text { Healthcare } \\
\text { Availability \& quality } \\
\text { of public and private } \\
\text { health care }\end{array}$ & $\begin{array}{l}\text { 2) Medical \& Health } \\
\text { considerations }\end{array}$ & 3) Medical care \\
\hline & $\begin{array}{l}\text { 3) } 25 \% \text { Culture } \& \\
\text { Environment } \\
\text { Climate, corruption, } \\
\text { social/ religious } \\
\text { restrictions, recreation: } \\
\text { sports, culture, food and } \\
\text { drink, availability of } \\
\text { consumer goods and } \\
\text { services }\end{array}$ & $\begin{array}{l}\text { 3) } \begin{array}{l}\text { Socio- Cultural } \\
\text { environment }\end{array} \\
\text { 4) Natural } \\
\text { environment } \\
\text { 5) Recreation } \\
\text { 6) Consumer goods } \\
\text { 7) Public Services }\end{array}$ & $\begin{array}{l}\text { 4) Climate \& sunshine } \\
\text { 5) Quality of } \\
\text { architecture } \\
\text { 6) Environmental issues } \\
\text { 7) Access to nature } \\
\text { 8) Urban design }\end{array}$ \\
\hline & $\begin{array}{l}\text { 4) } 10 \% \text { Education } \\
\text { Availability \& quality } \\
\text { of public \& private } \\
\text { education }\end{array}$ & 8) Schools \& Education & \\
\hline & $\begin{array}{l}\text { 5) } \mathbf{2 0} \% \\
\text { Infrastructure } \\
\text { International } \\
\text { Transportation modes } \\
\text { \& quality of public } \\
\text { transportation, } \\
\text { availability \& quality of }\end{array}$ & $\begin{array}{l}\text { 9) Housing } \\
\text { 10) Economic } \\
\text { environment }\end{array}$ & $\begin{array}{l}\text { 9) International } \\
\text { connectivity } \\
\text { 10) Public } \\
\text { Transportation } \\
\text { 11) Pro-active Policy } \\
\text { developments } \\
\text { 12) Business condition }\end{array}$ \\
\hline
\end{tabular}


Norimah Md Dali, Alias Abdullah \& Azila Ahmad Sarkawi

Liveability Planning for Cities: Within the Islamic Framework of Maqasid Al-Shari'ah

housing, utilities

amenities,

communications and

infrastructure

Table 2: Top ten rankings of world's liveable cities

\begin{tabular}{cllllll}
\hline \multirow{2}{*}{$\begin{array}{l}\text { Ran } \\
\mathbf{n}\end{array}$} & \multicolumn{2}{c}{ Monocle $(\mathbf{2 0 1 4})$} & \multicolumn{2}{c}{ EIU (2014) } & Mercer (2014) \\
\cline { 2 - 6 } 1 & City & Country & City & Country & City & Country \\
\hline 2 & Tokyo & Japan & Vienna & Austria & Zurich & Switzerland \\
3 & Melbourne & Australia & Vancouver & Canada & Auckland & New \\
& & Denmark & Melbourne & Australia & Vienna & Austria \\
4 & Stockholm & Sweden & Toronto & Canada & Munich & Germany \\
5 & Helsinki & Finland & Adelaide & Australia & Vancouver & Canada \\
6 & Vienna & Austria & Calgary & Canada & Dusseldorf & Germany \\
7 & Zurich & Switzerland & Sydney & Australia & Frankfurt & Germany \\
8 & Munich & Germany & Helsinki & Finland & Geneva & Switzerland \\
9 & Kyoto & Japan & Perth & Australia & Copenhagen & Denmark \\
10 & Fukuoka & Japan & Auckland & New & Bern & Switzerland \\
& & & Zealand & & \\
\hline
\end{tabular}

Table 3: The Asia's top liveable cities, 2014

\begin{tabular}{lcccl}
\hline Cities & $\begin{array}{c}\text { EIU } \\
\mathbf{( 2 0 3} \\
\text { cities })\end{array}$ & $\begin{array}{c}\text { MERCER } \\
\mathbf{( 4 6 0} \\
\text { cities })\end{array}$ & $\begin{array}{c}\text { ECA } \\
\mathbf{( 4 0 0} \\
\text { locations) }\end{array}$ & $\begin{array}{c}\text { Asia Rank/Top liveable } \\
\text { Asian Cities }\end{array}$ \\
\hline Singapore & 53 & 28 & 1 & 1. Singapore \\
Kuala Lumpur & 78 & 74 & 62 & 2. Kobe \\
Bangkok & 101 & 118 & 62 & 3. Hong Kong \\
Bandar Seri Begawan & 100 & 97 & 94 & 4. Tokyo \\
Manila & 107 & 128 & 142 & 5. Yokohama \\
Jakarta & 125 & 141 & 191 & 6. Taipei \\
Hanoi & 123 & 151 & 123 & 7. Macau \\
Ho Chi Minh City & 150 & 126 & 120 & 8. Georgetown \\
Phnom Penh & 130 & 190 & 171 & 9. Seoul \\
& & & & 10.Kuala Lumpur \\
\hline
\end{tabular}


Meanwhile, for Asian cities (Table 3), Monocle and Mercer rated them not liveable, even Singapore falls in 28th place by Mercer while EIU put Singapore at 53rd place. However, another organisation (ECA) acknowledged Singapore as the most liveable city in the world.

\section{Liveability and Urbanization - The Malaysian case}

Liveability and urbanization became a concern when people began to migrate from the rural areas to the urban centres since the Second Malaysian Plan period (1971-1975) (Alatas 1972). This was in line with the government's two prong strategy to eradicate poverty and to eliminate identification of race by their economic activities. Urbanization rate grew at a very fast pace and the urban population increased tremendously. It is projected that (The National Physical Plan 2010) more than $75 \%$ of the overall Malaysian population will live in towns and cities by the year 2020. As at the last population census, in 2010, total population stood at 28,334,135 people and the urbanization rate was $2.4 \%$. As of $1^{\text {st }}$ January 2015, the population of Malaysia was estimated to be 30,644,293 people (Government of Malaysia 2015) and rate of urbanization: $2.49 \%$ annual rate of change (2010-15 est.). It is therefore anticipated that the rapidly urbanizing trend will inflict increasing pressures on the urban services, health services, the housing and the economic sector and eventually the environment and natural resource reserves.

Meanwhile the lifestyles of the urban population worsen the health of the environment itself. Air pollution caused by motor vehicles is one source that are being generated by the urban population. The Malaysian Automobile Association (MAA) Statistics on total registered vehicles in Malaysia in 2000 was 343,173 units and in 2013 had increased double fold at 655,793 units. This shows that Malaysian car ownership per capita is high because for every 1000 Malaysians, 273 Malaysians own vehicles. Hence the culprit of the air pollution in Malaysian towns.

Other Urbanization issues that proof Malaysian towns are not so liveable include the water supply woes, traffic jams, air pollution index (API) more than 300 API incidences, flooding such as flash floods and monsoon floods, poor quality of life for example living in poor housing or slums, health problems, safety or high crime rates in housing neighbourhoods and everywhere, snatch thefts, etc.

The continuing increase of the rate of urbanization since the 70s until now requires the need for more systematic liveability planning, efficient administration and better delivery of services at the local authorities' level.

\section{Future of cities - Liveability, quality of life and sustainability package}

Generally, the future of cities is closely related to matters below:

i. A 'liveable future' is one that is enduring, vibrant, responsible (civil), and offers a desirable quality of life which need a balance of three key societal goals: vibrant communities, vital economy, and sustainable environment.

ii. Liveability and sustainability should be the guiding principle for planning and policy making. Concepts of Liveability, quality of life and sustainability as a package and a continuum should be emphasized in planning and implementation. 
Norimah Md Dali, Alias Abdullah \& Azila Ahmad Sarkawi

Liveability Planning for Cities: Within the Islamic Framework of Maqasid Al-Shari'ah

iii. Cities function as engines of growth. When cities grow the entire nation grows. Liveability shapes public perception and infrastructure investments in cities, as well as competition among cities for the attention of the public, investments, communities in future capitalistic economies.

iv. That liveability and sustainability often overlap and influence each other.

\section{Why is liveability important?}

i. Liveability is a measure of objective quality of life. People living in liveable cities are supposed to enjoy happy lives. It is important for people or its residents to be happy and make other people happy (Fowler and Christakis 2008). Meanwhile, according to the liveability theory, objective conditions such as infrastructure also make subjective wellbeing (Veenhoven and Ehrhardt 1995). These form basic requirements inevitable for urban living.

ii. For economic vibrancy.

Liveability is important for businesses - 'happy people are better workers' (Lyubomirsky et al. 2005).

iii. For good governance

Liveability is important for city governments, because liveable cities attract good workers and businesses, and business activity is the key for city development (Economist 2011).

\section{Liveability in the Context of Maqasid Al-Shari'ah}

This exercise will attempt to develop a new model based on the Maqasid Al-Shari'ah fundamentals. It does not mean that the conventional indicators used so far are not "Islamic" and universal but to a certain extent they carried Islamic messages internally. These need to be consciously spelled out because it deals with the human factor itself which is universal and affect everybody; Muslims and Non-Muslims alike. So the Islamic components will be integrated into the conventional measurements to render it holistic, comprehensive and complete. Table 4 is the framework on which this new model will be based upon. In terms of priority, Dharuriyyat is the most important, second comes the Hajiyyat and lastly the Tahsiniyyat. However, notice that, in terms of weightage, all five elements of the Maqasid Al-Shari'ah are given equal weightage (20\% each) unlike those given by the EIU in Table 1 earlier.

Table 4: The framework for the new model of liveability - the Maqasid Al-Shari'ah

\begin{tabular}{|c|c|c|c|}
\hline $\begin{array}{l}\text { MAS according } \\
\text { to hierarchy }\end{array}$ & $\begin{array}{l}\text { Dharuriyyat } \\
\text { (Necessities / } \\
\text { Essentials) }\end{array}$ & $\begin{array}{l}\text { Hajiyyat } \\
\text { (Needs / Complimentary) }\end{array}$ & $\begin{array}{l}\text { Tahsiniyyat } \\
\text { (Luxuries / Desirables) }\end{array}$ \\
\hline $\begin{array}{ll}\text { Din } & 20 \% \\
\end{array}$ & & & \\
\hline Nafs & & & \\
\hline Aql & & & \\
\hline Nasl & & & \\
\hline Maal & & & \\
\hline
\end{tabular}


Table 5 below shows the evaluation matrix of the five Maqasid Al-Shari'ah against the liveability Index of the world organizations which is represented by the three organizations; EIU, Mercer and Monocle while the MURNInet represent Malaysian sustainability Indicators. Focusing on the remarks column, it is found that in terms of preservation of life, the conventional liveability indicators show strong emphasis. Likewise for the intellect and property or wealth elements, the conventional indicators paid due attention to them. However, as far as Din and Nasl i.e. religion and lineage are concerned, they are either silent, minimally mentioned and did not mention at all.

Table 5: The Maqasid Al-Shari'ah matrix

\begin{tabular}{|c|c|c|c|}
\hline \multirow[t]{2}{*}{ The 5 Objectives } & \multicolumn{2}{|c|}{ Liveability Index } & \multirow[t]{2}{*}{ Remarks } \\
\hline & World & MURNInets & \\
\hline $\begin{array}{l}\text { Din } \\
\text { Preservation of } \\
\text { Religion }\end{array}$ & Social network & $\begin{array}{l}\text { Spirituality (under the } \\
\text { Happiness Index) }\end{array}$ & $\begin{array}{l}\text { - Not mention in the } \\
\text { Liveability Index } \\
\text { - Mention surficially in } \\
\text { Happiness Index }\end{array}$ \\
\hline $\begin{array}{l}\text { Nafs } \\
\text { Preservation of Life }\end{array}$ & $\begin{array}{l}\text { - Economic, social and } \\
\text { political stability } \\
\text { - Healthcare } \\
\text { - Culture \& } \\
\text { environmental } \\
\text { - Education } \\
\text { - Transportation }\end{array}$ & $\begin{array}{l}\text { - Economic efficiency } \\
\text { - Opt, landuse } \\
\text { - Social quality } \\
\text { - Sustainable } \\
\text { environmental quality } \\
\text { - Efficient } \\
\text { transportation \& } \\
\text { infrastructure } \\
\text { - Effective governance }\end{array}$ & $\begin{array}{l}\text { Complete } \\
\text { considerations on all } \\
\text { aspects of quality of } \\
\text { human living in both } \\
\text { the world and the } \\
\text { Malaysian } \\
\text { sustainability indicators }\end{array}$ \\
\hline $\begin{array}{l}\text { 'Aqal } \\
\text { Preservation of } \\
\text { Intellect }\end{array}$ & $\begin{array}{l}\text { Education: schools and } \\
\text { universities }\end{array}$ & Social facilities & $\begin{array}{l}\text { World index } \\
\text { emphasized on world } \\
\text { class universities }\end{array}$ \\
\hline $\begin{array}{l}\text { Nasl } \\
\text { Preservation of } \\
\text { Lineage } \\
\end{array}$ & Nil & $\begin{array}{l}\text { Relationship interaction } \\
\text { with family }\end{array}$ & $\begin{array}{l}\text { Not mention in the } \\
\text { world Indicators }\end{array}$ \\
\hline $\begin{array}{l}\text { Maal } \\
\text { Preservation of } \\
\text { Poperty }\end{array}$ & $\begin{array}{l}\text { Economic wellbeing, } \\
\text { high salaries, } \\
\text { economic stability }\end{array}$ & $\begin{array}{l}\text { Competitive and } \\
\text { efficient economic } \\
\text { development }\end{array}$ & $\begin{array}{l}\text { Being emphasized by } \\
\text { the world liveable } \\
\text { indicators }\end{array}$ \\
\hline
\end{tabular}

Understandably Western ideologies on life are all about progress, economic development and prosperity. Lineage which hinges on the sanctity of the marriage institution is very much distorted in the western and modern lives. People do not find it necessary to marry, they are free to have sex out of wed lock, free sex culture are rampant, homosexuality and lesbianism are commonly practiced and they do not favour to bear children. Relationships with parents and family ties have become very loose and the concept of filial piety has been eroded. These states of social affairs confronting the world today obviously show the non-compliance of human beings to the Maqasid al-Shariah hence the progression towards the doom of human civilization. Even western scholars acknowledged about this trend of the clash of civilizations of the future (Huntington 1996). 
Norimah Md Dali, Alias Abdullah \& Azila Ahmad Sarkawi

Liveability Planning for Cities: Within the Islamic Framework of Maqasid Al-Shari'ah

\section{RESEARCH METHODOLOGY}

To decide on the appropriate methodology, this study relates it with the Research Objectives and the Research questions. These are listed up as follows:-

\section{Research objectives}

1) To explore and evaluate current world liveability surveys that rank liveable cities which are based on their pre-determined sets of indicators and level of importance.

2) To study and highlight the Islamic human wellbeing indicators via the Maqasid Al-Shari'ah fundamentals.

3) To integrate the conventional world liveability indicators into the Islamic Maqasid Al-Shari'ah vice versa via developing an assessment tool or model.

4) To test and validate this model on Shah Alam and Putrajaya; as case studies.

\section{Research questions}

The research questions are interrelated to the research objectives as outlined above. They are:-

1) What are the strengths and weaknesses of the existing indicators used to determine and rank liveable cities?

2) Why are current liveability indicators inadequate and still cause liveability problems in the cities of the world? Can Maqasid Al-Shari'ah fill in the missing link?

3) How should Maqasid Al-Shari'ah be embedded or integrated into the conventional methodology of identifying liveable cities?

4) How can the developed model of assessing liveable cities once tested and validated be applied to all cities of the world for its liveability level?

This research will study on the effectiveness of town planning vis-à-vis the creation of liveability, happiness and quality of life for the people via efforts from the local authorities. This is measured through the Triangulation methodology by examining the planners' Islamic knowledge on Maqasid Al-Shari'ah against the local authority Councillors who execute the plan. A Content Analysis of the Putrajaya and Shah Alam Local Plans will be carried out to gauge the inclusion of the elements of Maqasid AlShari'ah in the plans. Interviewing experts in Maqasid Al-Shari'ah will enlighten the aspects that are missing in the plans that have been prepared and their implementation. The analysis will also be able to evaluate the similarities and differences between international liveable indicators against the Malaysian sustainability indices (MURNInets 2012).

This research engages in the combined methodologies involving Focus Group Discussions, Interviews and Perception surveys. The five tenets of the Maqasid AlShari'ah will be the measurement to gauge at which liveability point a town falls under. Since human lives are in two integral parts; the physical and the soul/spiritual, an analogy of the Yin and the Yang is appropriate where quality of life should strive towards the fulfillment and balance of both these aspects of human lives. Finally, the values and objectives of the Maqasid Al-Shari'ah will be incorporated into the conventional town planning practice and incorporate the Maqasid Al-Shari'ah principles to be embedded in the conventional liveability indicators of liveable cities. 
The research will highlight the weaknesses occurring especially in the vagueness of current planning policies and plan statements, the meaning and the concept of liveability in the Maqasid Al-Shari'ah context with its three levels of importance to human lives. Most importantly the surficial or minimal considerations of these values in the process of planning and its implementation will be highlighted.

Finally, the findings of this research will indicate an urgent need for change in the approach and practice of town planning in Malaysia in particular and the planning for world cities in general. Towards this light, developing the Islamic framework of the Maqasid Al-Shari'ah will contribute in making the whole liveability planning process of a city become a model to be emulated and applied by practicing town planners, quantity surveyors and architects of the built environment fraternity.

\section{CONCLUSION}

Liveability Planning that incorporates Islamic principles of Maqasid Al-Shari'ah could be the way forward to genuinely create liveable cities of the future. The spiritual and religious aspects that are found to be missing in the conventional liveable indicators could now be filled up with the five elements of Maqasid Al-Shari'ah-cum-indicators to gauge cities liveability levels. However what is most pertinent is not so much about the indicators per se but it is about the human factor itself. Human beings are responsible and accountable as "Khalifah" or vicegerents of the earth's resources. They have to consume them in a balanced manner so as to preserve, conserve and sustain them for the present generation and for future generation use. When this is consciously safeguarded, urban communities will live happy lives and finally render their cities liveable. City Managers and Town Planners will have to continually plan, monitor and facilitate developments of cities via Liveability Planning and Development strategies. When this happens, the motto in planning that emphasizes "planning by the people, for the people and by the people" is therefore deemed true in its real sense of liveability planning and liveable cities.

\section{ACKNOWLEDGEMENT}

The research for this paper was financially supported by the MyRA Incentive Research Grant Scheme (MIRGS) 2013 (Project ID: MIRGS 13-02-001-0005) Ministry of Education, Malaysia. We would like to thank the Government of Malaysia particularly the Ministry of Education, International Islamic University Malaysia and those who had contributed data, ideas, thought, motivation, supervision, guidance, assessment and the like in accomplishing this research.

\section{REFERENCES}

Ahris Yaakub, Healey, R. G., and Hughes, C. G. (1990). The Application of Geographic Information Systems for Urban Landuse Planning and Monitoring: A Case Study of Low-cost Housing Development in Kuala Lumpur, Malaysia. Environment and Planning B: Planning and Design, 17, 385-393.

Al, B. B. I. A. H. and Chik, W. M. Y. B. W. (2011). Maqasid Sharciyyah According To AlQaradawi In The Book Al-Halal Wa Al-Haram Fi Al-Islam', International Journal of Business and Social Science, Vol. 2, No. 1: 238-254.

Alatas, S. H. (1972) The Second Malaysia Plan 1971-1975: A Critique, Vol. 15. Institute of Southeast Asian. 
Norimah Md Dali, Alias Abdullah \& Azila Ahmad Sarkawi

Liveability Planning for Cities: Within the Islamic Framework of Maqasid Al-Shari'ah

Alias Abdullah. (1995). An Integrated Method of MCDM and GIS for Land Use Planning and Environmental Resources Management. Unpublished Ph.D. Thesis. Kumamoto, Japan: Kumamoto University.

Auda, J. (2008) Maqasid Al-Shariah as Philosophy of Islamic Law: A Systems Approach. IIIT.

Bakar, O. (2015) 'The place and role of Maqasid Al-Shari'ah in the ummah's twenty-first century civilizational renewal' in Islamic Civilisation and The Modern World: Thematic Essays, pp. 305-330, Gadong BE: Ubd Press.

Burton, I. (1987) Report on Reports: Our Common Future: The World Commission on Environment and Development. Environment: Science and Policy for Sustainable Development, Vol. 29: 25-29.

Contoh:

Economist. (2011) Liveanomics Urban liveability and economic growth. Economist Intelligence Unit.

Fowler, J. H. and Christakis, N. A. (2008) 'Dynamic spread of happiness in a large social network: Longitudinal analysis over 20 years in the Framingham heart study', British Medical Journal Vol. 337: a2338.

Government of Malaysia (1976) The Government Press, Kuala Lumpur The Town and Country Planning Act 1976, Act 172, Malaysia.

Government of Malaysia, Department of Statistics Malaysia, 2015.

Huntington, S. P. (1996) The clash of civilizations and the remaking of world order. Penguin Books India.

Kamali, H. M. and Kamali, M. H. (2008) Maqasid al-shariah made simple, Vol. 13. IIIT.

Lyubomirsky, S., King, L. and Diener E. (2005) The benefits of frequent positive affect: Does happiness lead to success? Psychological Bulletin, Vol. 131: 803

Miller D. J., and Sias J. (2000). Deciphering Large Landslides: Linking Hydrological, Groundwater and Slope Stability Models Through GIS. In Hydrological Applications of GIS, Guernell A. M. and Montrgomery D. R., eds. New York: John Wiley and Sons. 103-121.

MURNInets (2012) Malaysian Urban Indicators Network. Federal Town and Country Planning Department, Ministry of Housing and Local Government Malaysia.

National Physical Plan, Federal Department of Town and Country Planning, Ministry of Housing and Local Government, 2010.

Omer, Spahic. (2002). Studies in the Islamic Built Environment. Kuala Lumpur: Research Centre, International Islamic University Malaysia.

Rainis, R., Jaafar, N., and Mohd Zain, S. (2002). GIS-Based Decision Support System (DSS) for Monitoring and Simulating River Water Quality. Proceedings of the National Conference on Rivers '99, 14-17 October 1999, Penang. 263-269.

Sarkawi, A. A., Ibrahim, A. B. and Abdullah, A. (2008) The Contribution of Fiqh Al-Jinayat (Islamic Criminal Law) In the Planning Of a Safe City. Journal of the Malaysian Institute of Planners, No. 6: 19-38.

STEEP (2013) 'How to become the World's best city', STEEP, available from http://www.steep.fi/cases/research/2013/11/how-to-become-the-worlds-best-city/

Steiner, Frederick. (1999). The Living Landscape: An Ecological Approach To Landscape Planning. New York: McGraw-Hill, Inc.

Veenhoven, R. and Ehrhardt J. (1995) The cross-national pattern of happiness: Test of predictions implied in three theories of happiness. Social Indicators Research, Vol. 34: 33-68.

Winkel, E. (2011) Maqasid al-Shari'ah: A Literature Review. Islam and Civilisational Renewal, Vol. 2, No. 2. 